https://helda.helsinki.fi

\title{
Democracy, Critique and the Ontological Turn
}

\section{Mihai, Mihaela}

2017

Mihai , M , McNay , L , Marchart , O , Norval , A , Paipais , V , Prozorov , S \& Thaler , M

2017 , ' Democracy, Critique and the Ontological Turn ' , Contemporary Political Theory , vol.

pÿ16 , no. 4 , pp. 501531 . https://doi.org/10.1057/s41296-017-0140-0

http://hdl.handle.net/10138/297834

https://doi.org/10.1057/s41296-017-0140-0

acceptedVersion

Downloaded from Helda, University of Helsinki institutional repository.

This is an electronic reprint of the original article.

This reprint may differ from the original in pagination and typographic detail.

Please cite the original version. 
This is a post-peer-review, pre-copyedit version of an article published in Contemporary Political Theory, vol. 16, issue 4. The final authenticated version is available online at: https://doi.org/10.1057/s41296-017-0140-0.

\author{
Sergei Prozorov
}

1. Is political ontology merely the epochal form of critique at a time when alternatives to capitalism are often thought to be unimaginable?

Let us begin with the term 'political ontology'. I have never been comfortable with this concept, just as I am uncomfortable with the notion of 'political philosophy' more generally. It is difficult for me to understand how ontology as such, the theory or doctrine of being qua being, can actually be political (or economic, aesthetic, etc.). Just as the philosophy of music does not express itself in song and the philosophy of science makes precious few scientific discoveries, it is difficult to expect a philosophy or ontology of politics to itself have some political content, function or purchase. There are evident risks here of smuggling in such content from outside, imposing ontic content on an ostensibly ontological discourse.

The second problem is more specific to ontology. While we are accustomed to the idea of regional ontologies dealing with particular realms of beings, how ontological are they really? In the Heideggerian approach such 'ontologies' are clearly ontic, dealing with beings defined through their attributes and not the facticity of their being. From this perspective, to speak of ontology of film, dance, economy or politics is not to isolate a particular ontology for those domains, but to take 
them up solely in the dimension of their being, thus reducing or bracketing off their attributes. Political ontology or, better, ontology of politics would then be exactly the same ontology as the ontology of dance or economy: it would address the being of these beings or realms of beings without being in any way defined by them.

This is what I attempted to do in the first volume of Void Universalism (Routledge, 2013). There is no specifically political ontology in that book, only an inquiry on the relation between ontology and politics. And this relation is, in my argument, different from the relation between ontology and other procedures (art, science, religion, economy, etc). Ontology may not be political, but politics is certainly ontological, or, better, ontico-ontological. I define politics as a procedure of affirmation of universal axioms in any particular world. Following Badiou, I start out from the existence of an infinite number of infinite worlds defined by a particular positive order, whose condition of possibility is the void as 'the proper name of being', that in which and out of which all positive worlds emerge. The orders defining these worlds are contingent, relative and particular. However, if these worlds are reduced to their sheer being-in-the-void, we may derive axioms from this condition that would be necessary, absolute and universal. They define the very worldhood of any world whatsoever and for this reason are valid in any world whatsoever, since they do not depend on a single worldly trait. Thus, politics is an ontic practice (because it arises within a particular world) that traverses the ontological dimension (by means of the reduction of the world to its being, which Heidegger analyzed through such moods as anxiety and boredom) and then returns to the ontic realm to transform it in accordance with the axioms derived from the ontological one. From the world to the void and back again - this is the formula of politics, which is ontic in form but ontological in content, since its axioms (freedom, equality, community) are merely aspects of the being of all beings in all worlds. 
This ontological character also makes any genuine politics universalist - a point that goes against the grain of the contemporary historical-nominalist consensus, in which the only possible universalism may be a hegemonic one, which conceals its own particularity by necessarily false claims to universality. While it is true that no positive order of the world can attain universality, universally valid claims may nonetheless be grounded, not in the ontic attributes of the world but in its ontological conditions of possibility, i.e. the void. The three axioms of freedom, equality and community, which in my reading exhaust the content of politics, describe the being of any being of any world, when the specific attributes of this world are suspended. In the absence of any identitarian predicates defining what they are, we are left with the sheer fact that these beings are: equal (devoid of any hierarchy), free (from any determination) and in common (in the absence of any boundaries).

Thus, ontology (in the general and not 'regional' sense) provides politics with content that is irreducible to any particular world but can be affirmed in any world whatsoever. Evidently, this is a reconstitution of political praxis from a philosophical perspective: no political subject actuallychecks his or her actions against an ontological checklist. In the phenomenology of politics, addressed in the second volume of Void Universalism, the traversal of the ontological dimension takes the form of dis-identification from one's place in the world, the separation from one's prescribed identity that permits one to experience the world's order as wrong and venture to set it right. Disidentification is the ontic mode in which the subject encounters the ontological - again, similarly to Heidegger's encounter with being only in the situations when one's involvement with the world and its object is ruptured. 
This ontological theory of politics does not ascribe to politics any particular or distinct ontology, nor does it endow ontology with any particular political status. It is the same ontology as in physics, music or economy. What is distinct is rather the notion of politics that its linkage with ontology enables. In my view, the greatest danger for contemporary politics and the science of politics is the renunciation of the universal in a historico-cultural nominalism that proclaims that there are only particular worlds, with their own particularistic politics, and nothing beside them. This is true nihilism in the Heideggerian sense - not the affirmation of the nothing at the heart of all things but its nullification, the reduction of this nothingness to nothingness, whereby what there is is all there is and there is no standpoint from which these particular, relative and contingent worlds may be problematized, found wanting, judged and possibly transformed. This nihilistic disposition is suicidal for both politics, which remains riveted to the particular order of the world it finds itself in, and especially for political science, which ends up devoid of any instrument for a meaningful discourse on politics. Politics becomes merely a name for whatever a given world order wants to mean by politics and no 'cross-worldly' translation is even possible.

I can now attempt to answer the question: if 'political ontology' is to be historicized as an epochal critique, it is probably not a response to the disappearance of alternatives to capitalism, but a response to this weakening of the universal dimension of politics: the reduction of politics to the strictly ontic (culture, discourse, language game). But it is precisely by insisting on that universal dimension, that the ontological turn actually creates an alternative to capitalism, which in recent decades has attempted to establish its elf as the only universal there is (general equivalent of money as the only thing different worlds have in common). Ontology of politics supplements this claim: besides money, there is also freedom, equality and community, however much disavowed they might be in any given world. 


\section{Have we exhausted the intellectual and practical resources of other forms of critique, such as feminist, post-colonial or Marxist approaches?}

In their own ways feminist, post-colonial and Marxist approaches share this claim about freedom, equality and community as universals and in this sense participate in 'ontology of politics' broadly defined. However, all three are also tempted by the historical-nominalist tendency to disavow the universal. This is particularly understandable for feminist and post-colonial scholarship, for which the problematization of the false universality claims of the hegemonic white-Western-male-etc subjectivity was historically constitutive. But this is also true for Marxisms of various stripes, which all shared the fundamental logic of the passage to true universality via the demolition of the falsity of the claims to universality of the liberal-democratic capitalist order.

Of course, the exposure of false universalism is important, as long as we understand that what is actually criticized in it is not universalism (which is missing), but particularism, which conceals its own hegemonic particularity by pretending to be universal. There thus arises the question: is a proper, non-hegemonic universalism possible? If not, this critique actually makes little sense: if particularism with more or less hegemonic as pirations is all we can get, then why criticize hegemonic particularism other than to urge it to abandon the name of universalism? The risk is that critical discourse thereby begins to resemble the most hackneyed formulae of 'political realism' in international relations: 'all there is' is struggle for power or hegemony between particularistic entities with no universal principles to adjudicate them; might makes right, and so on. The only 
difference is that while many political realists affirm this state of affairs, the representatives of critical approaches would decry it, but still come to terms with it as the 'tragic' character of the human condition. However, the pathos of tragedy seems a bit premature, since the re is nothing necessary about the renunciation of the universal. Things do not have to be so tragic unless you want them to be.

If, on the other hand, proper universalism is possible, then the critique gains in force, but only insofar the universalist affirmation is explicated. It is here that the ontological turn becomes so important, not as an alternative approach to replace feminism, post-colonialism or post-Marxism but as an injunction to greater sensitivity and reflection about the ontological status of the central concepts of our critical theories. It is therefore the very opposite of the retreat from the concrete reality of politics into the abstract discourse on being: what is at stake is rather precisely the intervention into discourses on politics that has no other foundation than the universality and the singularity of being itself, which, we recall, is only ever the being of beings, these beings, here and now. Paradoxically at first glance, the re-engagement with the universal through ontology will actually help us reconnect with the singular, which we lose sight of when we are focused too much on the categories of social identity (class, gender, race).

\section{What new forms of political imagination can animate critique and re-invigorate democratic} practices?

This question takes us back to the relation between politics and philosophy/theory/science that we started with. I think that there is something dubious in the expectation that the study of politics will 
itself have political effects. Philosophy of politics can meaningfully take politics as an object only on the condition that it does not introduce its own content into it, otherwise it will end up studying its own message. Philosophy cannot ground politics because politics has its own autonomous consistency as a transformative praxis within a particular world. It has its own modus operandi, its own rationality, its own imagination etc., that may well be inaccessible to the philosopher of politics who after all need not even be involved in politics in any way. It is a bit ludicrous to expect that I as a philosopher can tell people involved in an uprising, staging a protest or even going to polls, what they should do and how, who they should vote for, etc. How would I know that and why would anyone listen?

Moreover, there is an important difference between politics and philosophy that deserves to be mentioned. Politics is about acting on the basis of the universal axioms in adverse circumstances, which involves not only personal courage and conviction, but also enormous efforts at gaining adherents, forming coalitions, perpetually broadening the, etc. The political subject seeks to maximize the others' agreement with his or her disagreement with the world. In contrast, the philosopher does not seek agreement, which usually means only that his argument is perfectly trivial, but rather ventures to develop a singular interpretation that would be distinct from others. The philosopher does not build coalitions but accentuates divisions, which makes his mode of praxis politically us eless or even counter-productive. There is nothing wrong with two experts having three different opinions in the context of an academic conference, but this would be quite unhelpful in the context of a protest demonstration.

Yet, there is also the opposite risk. Just as politics cannot be grounded by philosophy, it cannot become its ground, reducing philosophy to something like the continuation of class struggle in 
theory. As the fate of philosophy in nominally Marxist political regimes demonstrates, such politicization can only reduce philosophy to useless drivel without really helping class or any other struggle. Again, the contrast between the two procedures permits us to see why this is the case. Politics operates with three axioms, which remain fairly indeterminate, and it is the task of the political subject to determine their meaning in the concrete world in which they are to be applied. Political knowledge thus comprises very basic axiomatic content and a myriad of practical skills and orientations that are opportunistic in a neutral sense of the word, cultivating concrete opportunities for political affirmation. If this knowledge becomes the foundation for philosophy, it directs the latter either to the trivial reiteration of the well-known or to the ceaseless justification of ad hoc opportunistic actions. Putting philosophy in the service of 'progressive politics', whatever we mean by this, will only yield bad philosophy while adding nothing to the political cause.

In short, neither philosophy nor politics can found one another without losing the essential features of one or both procedures. It is therefore not really up to philosophy to reinvigorate democratic practices or even animate critique. There are properly political instruments for doing that and a politics that really needs re-animation from philosophy is well and truly dead. What is to be done is not to animate or reinvigorate politics but simply to practice it whenever we experience our worlds as wrong. 